\title{
高齢者施設居住における接客空間のしつらえ方に関する研究 A STUDY ON THE SETTING OF RECEPTION IN NURSING HOMES
}

\author{
藤枝秀樹***, 木下誠一**, 今井正次* \\ Hideki FUJIEDA, Seiichi KINOSHITA and Shoji IMAI
}

\begin{abstract}
This paper aims the planning suggestions of the reception space from residents' and visitors' requirements and claims in nursing homes. They require the environment as their"house"'s one through reception. So we investigated the actual situation of reception in nursing homes . We questioned visitors and observed to nursing homes, on the reception places, reception behavior .

(1)The staffs help of reception is important. The supportive settings must be near for reception spaces.

(2)The table space for reception is necessary in the residential room.

(3)The table layout of the dining room must match all residents' dining and one family's one.

(4)The living room must have setting differnt from residential room.
\end{abstract}

Keywords:Visitor,Residents, Receptions, Setting,Nursing home

訪問客、入居者、接客環境、しつらえ、高齢者居住施設

\section{1.はじめに}

\section{1-1. 研究の背景}

家庭的環境の中で、住居と社会とを結びつける大切な行為として 接客があげられ、古くから、さまざまな接客空間が住居の中で創ら れてきた。石毛 ${ }^{1)}$ は、「人間の住居と動物の住居の違いのひとつ は、人間の住居は客を招じいれる設備でもある」と述心゙、人間に とっての接客空間の大切さを示している。現在、国の高齢者施設整 備注1) は入居前の居宅における生活と入居後の生活が連続した家庭 的環境の実現を目指して進められている。つまり、高齢者施設を住 居として捉えると、高齢者施設居住において接客空間は重要な空間 となると位置づけることが出来る。

高齢者居住施設での接客空間について言及している研究として、 林・小滝・林 2) は、特別養護老人ホームの個室において、接客が多い 入居者の家具配置に特徵があることを捉えている。橘・外山・高橋・古 賀 ${ }^{3)}$ は、個室型特別養護老人ホームにおける個室内の家具レイアウ 卜、持ち込み家具のセッティング・使われ方状況から居室における訪 問客に対応した個人的領域形成注2）の特性を明らかにした。いずれ も、高齢者自身の生活の場における居住環境整備要件のひとつとし て接客を捉えたもので、訪問客との接客行為の状況を捉えて高齢者 居住施設環境を考察した研究はみられない。

\section{1-2. 高齢者居住施設における接客}

既論文 ${ }^{4)}$ で述べたとおり、接客の意義の一つに、家の中で「快 適な時間を共有すること」注3) が挙げられる。つまり、本稿では接
客を、高齢者施設に住むホスト=入居者注4）の応対、あるいはスタッ フの支援、訪問客の協力によって「入居者と訪問客がひと時を共に 快適に過ごすことができる場面」が施設の中でつくられることと定 義する。また、訪問客が介護をしながら会話が行われている場合も 同様である。尚、本稿における「しつらえ」は接客時に関わる家 具・敷物・浴槽などの設備、畳・障子・空等の内装注5) をいう。

\section{1-3. 研究の目的}

本稿は、高齢者居住施設における入居者と訪問客の接客を対象と し、施設における接客場所選択要因、接客場所注6)の「しつらえ」 と接客行為内容の関係性・特性を明らかにすることによって、接客 空間の「しつらえ」整備の要件抽出を目的とした。

\section{1-4. 研究の方法}

接客空間の「しつらえ」整備の要件抽出を目的として、以下の課 題を設定した。

（1）施設が個人空間から共用空間まで多様な空間があること、複数 の入居者とスタッフが共同で生活していることから、「接客場所の 把握とその選択要因」、「接客場所と他入居者との関係性とその空間 的特性」、「スタッフの対応状況の把握とスタッフが対応しやすい接 客空間の特性」を明らかにする。

(2) 既論文の施設居住に伴う変容 ${ }^{4}$ )をみると、 3 時間以上の長時 間滞在で接客が行われた事例は、旧自宅 2 割弱 $(12 / 69$ 事例)、施 設は 4\%（5/126 事例）と施設は旧自宅より大幅に割合が少ない 注7)。このことは、施設が長時間滞在に対応した接客空間整備が不

$\begin{aligned} * \text { 三重短期大学 教授·工博 } & \text { Prof., Tsu City College, Dr. Eng. } \\ \text { ***三重大学大学院工学研究科 助教·工修 } & \text { Research Assoc., Graduate School of Eng., Mie University, M. Eng. } \\ \text { ** } & \text { NAITO Architects Co., Ltd., Dr. Eng. }\end{aligned}$


十分であると推察され、必要な整備要件が求められる。本稿では、 事例毎に滞在中の移動場所、接客行為、使った「しつらえ」を抽出 し、全般的な傾向とその要因を整理する。

（3）接客場所での接客行為に対し、「しつらえ」の状況把握とその 特性を明らかにし、高齢者居住施設の接客場所に求められる「しつ らえ」の要件を抽出する。

\section{$1-5$. 調查施設}

調查施設は、多様な高齢者居住施設での接客空間を把握するた め、厚生労働省が示す「介護保険で受けられる施設サービス」注8) 全般及び施設で共同生活する在宅サービスの施設種を対象とし、特 別養護老人ホーム (小規模単位型注 9 ) $) 3$ 施設、療養型病院 1 施設、 老人保健施設 1 施設、グループホーム 1 施設、ケアハウス 1 施設の 計 7 施設で調查を行った（表 1 )。

\section{1-6. 調査の方法}

調查は高齢者居住施設において普段から接客が少ない状沉注 10) 及 び施設側の入居者への配慮・入居者の認知症等の容態を考慮して、 「訪問客へのアンケート調查」、「訪問客追跡調查」、「定時間隔観察 調查」の中で施設が認める方法により行い、より多くの接客事例収 集に努めた。また、ケアハウスは、入居者の自立度が高く個人のプ ライベートな生活が中心である為、生活状況・接客状況が間接的に 把握することが難しく、入居者に直接ヒアリングを行った（表 2 ）。 さらに、定時間隔観察調查によって「接客時のスタッフの対応状況 の把握」及び「訪問受入居者注4) の 1 日の居場所と訪問客の滞在場 所との関係性の把握」を行った。尚、調查対象入居者の基本属性 · 調查事例数は表 3 に示寸。

表 1 施設の概要

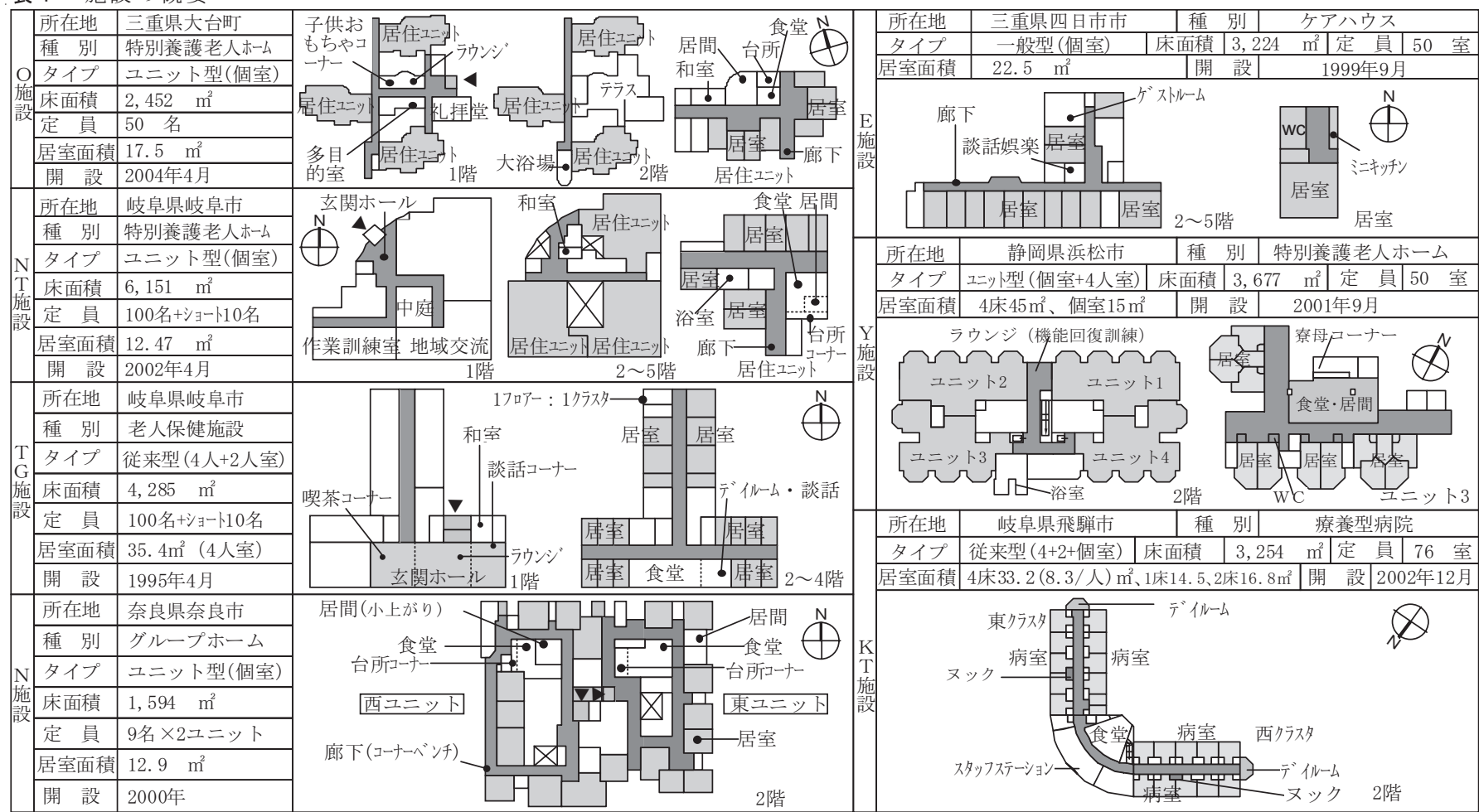

表 2 調查概要

\begin{tabular}{|c|c|c|}
\hline & 調查番号·設問項目·調查項目 & 設問•調査内容 \\
\hline \multirow{5}{*}{ (1) } & 訪問客アンケート調査 & 施設を訪れた訪問客に調査票を配布し、 \\
\hline & 今回の訪問について(記述) & 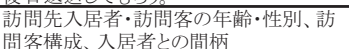 \\
\hline & 今回の訪問について(図面記入) & $\begin{array}{l}\text { 接客時・時間・場所・行為、訪問先入居 } \\
\text { 者の様子、使ったしらえとその配置 }\end{array}$ \\
\hline & 訪問客の要望(記述) & 訪問するに当たり建物・部屋に対する要 \\
\hline & 今回以外の接客(記述、複数回答) & $\begin{array}{l}\text { 訪問先入居者との間柄、接客日時·時 } \\
\text { 間·場所·行為、使ったしらえ }\end{array}$ \\
\hline \multirow{4}{*}{ (2) } & $\begin{array}{l}\text { ユニ外・クラスタ入居者 } \\
\text { 定時間隔観察調査 }\end{array}$ & 15分毎に図面に記述する。 \\
\hline & 入居者について(図面記入) & $\begin{array}{l}\text { 1日の居場所・行為内容・関係するしつら } \\
\text { 之 }\end{array}$ \\
\hline & スタッフについて(図面記入) & $\begin{array}{l}\text { 1日の居場所・行為内容・関係するしつら } \\
\text { え }\end{array}$ \\
\hline & 訪問客について(図面記入) & $\begin{array}{l}\text { בニット・クラスタへ入退出までの居場所・ } \\
\text { 行為内容・関係するしららえ }\end{array}$ \\
\hline \multirow{2}{*}{ (3) } & 訪問客追跡調査 & $\begin{array}{l}\text { 訪問から帰宅するまで分単位で図面に記 } \\
\text { 述する。 }\end{array}$ \\
\hline & 訪問客について(図面記入) & 居場所・行為内容·関係したしつらえ \\
\hline \multirow{3}{*}{ (4) } & 入居者ヒアリング調査 & 入居者への聞き取り調查 \\
\hline & 旧自宅での生活について & $\begin{array}{l}\text { 建物種別·室数·接客場所・接客行為内 } \\
\text { 容·訪問客との関倸·関係したしつらえ }\end{array}$ \\
\hline & 施設での生活について & $\begin{array}{l}\text { 室数·日中居場所·接客場所·行為・しつ } \\
\text { らえ·訪問客 } の \text { 関倸·客場所の望 }\end{array}$ \\
\hline
\end{tabular}

表 3 調査対象入居者及び訪問客の基本属性

\begin{tabular}{|c|c|c|c|c|c|c|c|}
\hline \multicolumn{8}{|c|}{ ユニット・クラスタ入居者定時間隔観察調査 } \\
\hline 施設名 & $\mathrm{O}$ & $\mathrm{O}$ & NT & NT & NT & NT & TG \\
\hline 階.エニット・クラスタ & $2 \mathrm{~F}$ 北ユニット & 2F南ユニット & 4F北ユニット & 4F北ユニット & 4F西ユニット & 4F西ユニット & 3Fクラスタ \\
\hline 時間 (開始時間分.終了時間分) & 0830.2000 & 0830.2000 & 0800.2000 & 0800.2000 & 0800.2000 & 0800.2000 & 0830.2000 \\
\hline 調査日 (西暦年月日曜日) & 051129火 & 051213火 & \begin{tabular}{|l|l|}
$051023 日$ \\
\end{tabular} & \begin{tabular}{|l|l}
051027 木 \\
\end{tabular} & \begin{tabular}{|l|l|}
$051023 日$ \\
\end{tabular} & 051027木 & 051215木 \\
\hline ユニット・クラスタ入居者数 & 8 & 8 & 7 & 7 & 8 & 8 & 44 \\
\hline 調査対象入居者数 (人) & 8 & 8 & 7 & 7 & 8 & 8 & 17 \\
\hline 入居者平均年齢 (歳) & 86 & 84 & 81 & 81 & 82 & 82 & 86 \\
\hline 入居者平均寝たきり度 & B1 & B1 & $\mathrm{B} 1$ & B1 & B1 & $\mathrm{B} 1$ & $\mathrm{~B} 1$ \\
\hline 接客事例数 & 0 & 0 & 0 & 1 & 3 & 1 & 7 \\
\hline 接客事例入居者平均年齢(歳) & - & - & - & 78 & 82 & 86 & 80 \\
\hline 接客事例入居者平均寝たきり度 & - & - & - & $\mathrm{B} 2$ & B1 & A1 & B1 \\
\hline 接客率 & $0 \%$ & $0 \%$ & $0 \%$ & $14 \%$ & $38 \%$ & $13 \%$ & $16 \%$ \\
\hline 訪問客アソケート調查:O(1)は1F西き & 此入居者1 & 間隔観 & 查を同旺 & 行5, $\mathrm{OC}$ & は訪問 & 直接ヒアリング & 入居者切 \\
\hline 施設名 & $\mathrm{O}(1)$ & $\mathrm{O}(2)$ & $\mathrm{O}$ & NT & TG & $\mathrm{N}$ & $\mathrm{E}$ \\
\hline 配布・ヒアリング日(西暦年月日曜日 & 050618土 & 051129土 & 051128月 & 051023日 & 051215木 & 051227火 & 050123日 \\
\hline 回答数 $($ 人 $)$ & \begin{tabular}{|l|l|}
5 \\
\end{tabular} & 1 & 11 & 24 & \begin{tabular}{|l|l|}
23 \\
\end{tabular} & 4 & 5 \\
\hline 接客事例数 & 5 & 1 & 21 & 60 & 51 & 14 & 6 \\
\hline 接客事例入居者平均年齢(歳) & 83 & 70 & 81 & 83 & 88 & 83 & 85 \\
\hline 接客事例入居者平均寝たきり度 & $\mathrm{C} 1$ & A1 & B1 & B1 & $\mathrm{B} 2$ & A2 & A1 \\
\hline 訪問客 $\sigma$ 平均年齢(歳) & & 42 & 53 & 54 & 58 & 55 & \\
\hline 訪問客追跡調査: & 穴·3は入展 & 者30分間 & 滒観察調査を & 同時に行 & & 調查事 & 例数 \\
\hline 施設名 & $\mathrm{Y}$ & $\mathrm{Y}$ & $\mathrm{Y}$ & KT & $\mathrm{N}$ & 接客事例計 & 222 \\
\hline 階.ユニット・クラスタ & $2 \mathrm{~F}$ ユニニト1 & 2Fユニット2 & $2 \mathrm{~F}$ ユニット3 & 2Fクラスタ & 2F東ユニット & しつらえがわ & 144 \\
\hline 時間(開始時間分.終了時間分) & 1000.2000 & 1000.2000 & 1000.2000 & 0800.2000 & 1100.1500 & かる事例 & $65 \%$ \\
\hline 調査日(西暦年月日曜日) & \begin{tabular}{|l|}
$011201 土$ \\
\end{tabular} & 031025 土 & 031025 土 & 030412 土 & 041007木 & 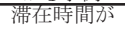 & 201 \\
\hline ユニット・クラスタ入居者数 & 11 & 14 & 11 & 74 & 9 & わかる事例 & $91 \%$ \\
\hline 接客事例数 & 2 & 4 & 4 & 41 & 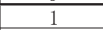 & \begin{tabular}{|l|l} 
接客前後居 \\
\end{tabular} & 37 \\
\hline 接客率 & $18 \%$ & $29 \%$ & $36 \%$ & $55 \%$ & $11 \%$ & 場所わかる & $17 \%$ \\
\hline
\end{tabular}




\section{2. 訪問受入居者の居場所と接客場所}

施設特有の接客の特性をみるため接客場所をどのように展開して いるかその実態を把握する。接客前後に訪問受入居者が居た場所が わかる事例は、対象の 222 事例の内 37 事例（2 割弱）あった（表 3 )。

\section{2-1. 訪問受入居者が居た場所で接客が行われた事例}

接客時の様子がわかる 37 事例（表 4）のうち、訪問受入居者が移 動せずに居た場所で接客が行われた事例は、16 事例（4 割強）あっ た。接客場所をみると居室が 10 事例（7 割弱)、食堂 4 事例（2 割強） である。居室では、個室が 10 事例中 7 事例（7 割）と多くを占め、 その全ての事例で扉を閉めて訪問受入居者と訪問客だけの接客空 間となっている。

次に、食堂の事例をみると、全てユニット型施設の事例である。
また、食堂の事例の全ての訪問受入居者について日中の過ごしてい る場所をみると 1 日の 8 割以上（表 4 、居室での睡眠除く）を食堂 で過ごしている。接客時の様子は訪問客は訪問受入居者の横に座っ て会話やレクリエーションを楽しんでいる。つまり、訪問受入居者 が訪問客と水入らずで会話することが出来る場所に居た事、訪問受 入居者が多くの時間を過ごす場所であるとともに訪問客が横に座っ て会話することが出来る場所である事が訪問受入居者が移動せずに 居た場所で接客が行われる要因となっている。

\section{2-2. 訪問受入居者の居場所から移動して接客が行われた事例}

訪問受入居者の居場所から移動して接客が行われた事例をみると (表 4)。3 7 事例の内、2 1 事例（6 割弱）と入居者が居た場所で行 う事例より多い。居室からの移動は 21 事例中、6 事例（3 割弱）ある

表 4 接客時の様子

\begin{tabular}{|c|c|c|c|c|c|c|c|c|c|c|c|c|c|c|c|c|c|c|c|c|c|c|c|c|c|}
\hline & & & & 居者 & & & 訪問客 & & & & & & & 移重 & & & & & & & & & & & \\
\hline 番 & & & 性 & 年路 & 㥶 & 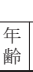 & 間柄 & 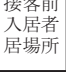 & 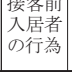 & 接客場 & 接客時 & 場所移動の様子、行為内容、入居者·訪問客の特徴 & 個室 & 個 & & 堂堂当 & 内 & \begin{tabular}{l|l} 
食 \\
尿
\end{tabular} & 外 & \begin{tabular}{|l|} 
食 \\
外 \\
\end{tabular} & 居 & & 個 & $\begin{array}{c}\text { 型(移動 } \\
\text { sL虽 } \\
\text { 中) }\end{array}$ & \\
\hline 1 & & 個室 & 女 & 96 & B1 & $\begin{array}{l}68 \\
75 \\
\end{array}$ & 次女夫婦 & 居間 & 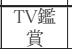 & 廊下 & 找茶 & 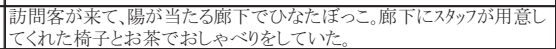 & & & & & & & & & & 0 & & & \\
\hline 2 & & 個室 & 男 & 78 & $\mathrm{C} 2^{2}$ & $\begin{array}{l}76 \\
28 \\
\end{array}$ & 妻娘 & 食堂 & 睡眠 & 居室 & おやつ & 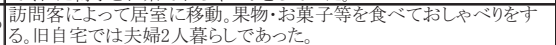 & & & & & & & & & O & & & & \\
\hline 3 & O & 個室 & 女 & 70. & A1 & 42 & 娘 & 食堂 & 徘徊 & 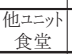 & 食事 & 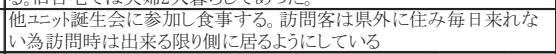 & & & & & & & & 0 & & & & & \\
\hline 4 & & 個室 & 男 & 83 & c1 & 栄 & 娘孫 & 居室 & 睡眠 & 居室 & 会話 & 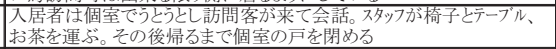 & ○ 閉 & & & & & & & & & & & 0 & \\
\hline 5 & & 個室 & 男 & 74 & B2 & 明 & 妻 息子 & 居室 & 睡眠 & 居室 & 会話 & 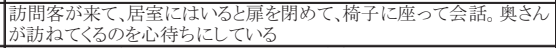 & O閉 & & & & & & & & & & & 0 & \\
\hline 6 & & 個室 & 男 & 73 & 42 & 47 & 息子 & 居室 & 不明 & 居間 & 会話 | & 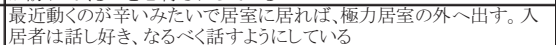 & & & & & & 0 & & & & & & & \\
\hline 7 & & 個室 & 女 & 62 & $c_{2}$ & 66 & 夫 & 食堂 & 不明 & 居室 & 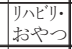 & 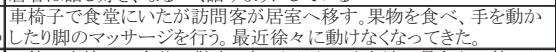 & & & & & & & & & o & & & & \\
\hline 8 & $=$ & 個室 & 女 & 74 & $c 1$ & $\begin{array}{ll}41 \\
10\end{array}$ & 長男 孫 & 食堂 & 飲食 & $\begin{array}{c}\text { 工朴外 } \\
\text { 廊下 }\end{array}$ & 散歩 & 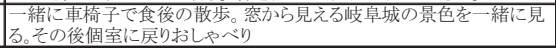 & & & & & & & & 0 & & & & & \\
\hline 9 & & 個室 & 男 & 80 & A1 & $\begin{aligned} 55 \\
54 \\
74\end{aligned}$ & 娘夫婦 & 居室 & \begin{tabular}{|c|c|} 
音箕鑑 \\
\end{tabular} & 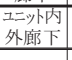 & $\begin{array}{ll}\text { 会話· } \\
\text { 散歩 } \\
\end{array}$ & 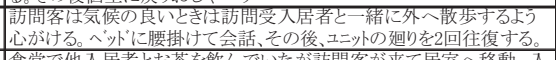 & & & & & & & 0 & & & & & & \\
\hline 10 & 型倜 & 個室 & 女 & 97 & $B 2$ & 80 & 娘夫婦 & 食堂 & 飲及物 & 居室 & おやへ & 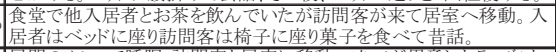 & & & & & & & & & $\circ$ & & & & \\
\hline 11 & 室 & 個室 & 男 & 82 & J & $\begin{array}{ll}71 \\
48 \\
\end{array}$ & 妻娘 & 居間 & 睡眠 & 居室 & おやへ & 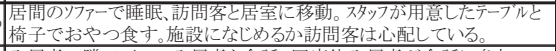 & & & & & & & & & & & 0 & & (1) \\
\hline $12 \mathrm{~N}$ & & 個室 & 男 & 86 & B1 & 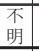 & 娘 & 食堂 & 無為 & 食堂 & 会話 & 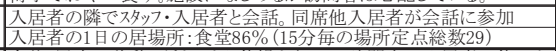 & & & & 0 & & & & & & & & 0 & \\
\hline 13 & & 個室 & 女 & 89 & B2 & 59 & 息子夫婦 & $\begin{array}{ll}\text { 食堂 } \\
\end{array}$ & 食事 & 居室 & 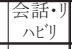 & 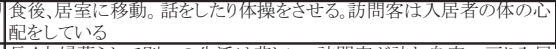 & & & & & & & & & 0 & & & & \\
\hline 14 & & 個室 & 女 & 85. & $\mathrm{A1}$ & $\begin{array}{l}88 \\
73 \\
\end{array}$ & 夫 親戚 & 食堂 & $\begin{array}{l}\text { TV艦 } \\
\text { 賞 } \\
\end{array}$ & 居室 & おやつ & 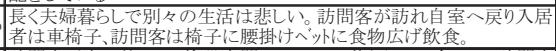 & & & & & & & & & o & & & & \\
\hline 15 & & 個室 & 女 & 88 & $\mathrm{A1}$ & 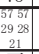 & 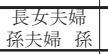 & 食堂 & 会話 & $\begin{array}{l}\text { TG玄 } \\
\text { 関机 } \\
\end{array}$ & おやつ & 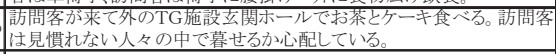 & & & & & & & & 0 & & & & & \\
\hline 16 & & 個室 & 男 & 81 & $\mathrm{~A} 2$ & 不 & 不明 & 居間 & 無為 & 居間 & おやつ & 訪問客がおやつのバナナを食どさせる。 & & & & & $\circ$ & & & & & & & 0 & \\
\hline 17 & & 個室 & 女 & 62 & $\mathrm{c} 2$ & $\begin{array}{l}\text { 不 } \\
\text { 明 }\end{array}$ & 不明 & 居室 & 睡眠 & 居室 & 会話 & 訪問客3人来て椅子に座って居室の屝締めて中で会話 & $\bigcirc$ 閉 & & & & & & & & & & & 0 & 2 \\
\hline 18 & & 個室 & 女 & 86 & 42 & 否 & 不明 & 居室 & 睡眠 & 居室 & 会話 & 掌閉める。訪問客か & $O$ 閉 & & & & & & & & & & & 0 & \\
\hline 19 & & $\begin{array}{ll}\text { 居室 } \\
\end{array}$ & 女 & 87 & 32 & $\begin{array}{ll}63655 \\
33 \\
\end{array}$ & $\begin{array}{l}\text { 長女省婦 } \\
\text { 棌 }\end{array}$ & 居室 & 不明 & 糹関粎 & 食事· & 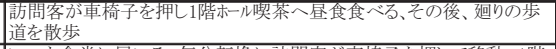 & & & & & & & O & & & & & & \\
\hline 20 & 多 & 年居窒 & 女 & 95 & B1 & 杯 & 子供 & 食堂 & 不明 & 芸関林 & 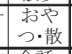 & 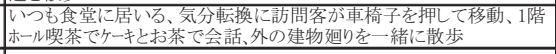 & & & & & & & & 0 & & & & & \\
\hline trat & 施㢈 & \begin{tabular}{|l} 
居室 \\
\end{tabular} & $\begin{array}{ll}\text { 不 } \\
\end{array}$ & 熶 & B1 & $\begin{array}{l}37 \\
5 \\
\end{array}$ & 長男孫 & 食堂 & $\begin{array}{l}\text { 徘徊 } \\
\end{array}$ & 䒚関杜 & $\begin{array}{ll}\text { 会詰. } \\
\text { 散步 } \\
\end{array}$ & 訪問客が散歩に連れだし、1階本一ルー移動し会話する & & & & & & & & 0 & & & & & \\
\hline 22 & 室 & $\begin{array}{l}\text { 居室 } \\
\end{array}$ & 女 & 83 & 不 & 57 & 娘夫婦 & 食堂 & 不明 & 蒓関朴 & 求茶 & 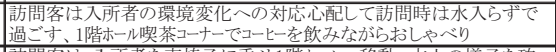 & & & & & & & & 0 & & & & & \\
\hline 23 & & $\begin{array}{ll}\text { 居室 } \\
\end{array}$ & 女 & 85 & B2 & $\begin{array}{c}55 \\
53 \\
\end{array}$ & 息子夫婦 & 居室 & 不明 & 而関杜 & 求やつ & 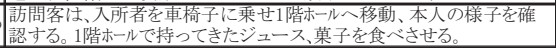 & & & & & & & 0 & & & & & & \\
\hline 24 & $\begin{array}{l}N \\
t\end{array}$ & 個室 & 女 & 80 & $\mathrm{A1}$ & 47 & 長男嫁 & $\begin{array}{l}7=\text { 帅内 } \\
\text { 郎下 } \\
\end{array}$ & 徘徊 & $\begin{array}{l}\begin{array}{l}\text { ב次内 } \\
\text { 廊下 }\end{array} \\
\end{array}$ & 会話 & $\begin{array}{l}\text { 訪問時一人で俳 } \\
\text { して㽎下のベンチ }\end{array}$ & & & & & $\circ$ & & & & & & & 0 & \\
\hline 25 & 設個 & 個室 & $\begin{array}{ll}\text { 男 } \\
\text { 女至 } \\
\end{array}$ & $\begin{array}{l}89 \\
84 \\
\end{array}$ & $\mathrm{A1}$ & 60 & 長女 & 食堂 & \begin{tabular}{|l|} 
趣味 \\
(㥒棋) \\
\end{tabular} & 食堂 & 会話 & 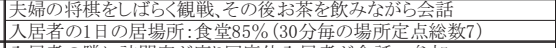 & & & & 0 & & & & & & & & 0 & \\
\hline 26 & & $\begin{array}{ll}\text { 居室 } \\
\end{array}$ & 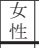 & $\begin{array}{ll}70 \\
\text { 代 } \\
\end{array}$ & $\mathrm{J} 2$ & 代 & 娘 & 食堂 & 無為 & 食堂 & 会話 & 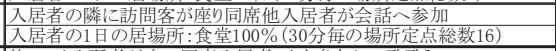 & & & & 0 & & & & & & & & 0 & \\
\hline 27 & 個 & \begin{tabular}{|l|l|l|} 
居室 \\
\end{tabular} & 女 & 盟 & A2 & 代 & 他入居者 & 食堂 & 無為 & 食堂 & 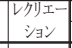 & 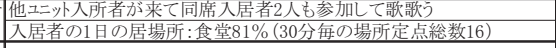 & & & & 0 & & & & & & & & 0 & \\
\hline 28 & 的 & $\begin{array}{ll}\text { 居室 } \\
\end{array}$ & 男 & 否 & A2 & 代 & 息子 & 食堂 & $\begin{array}{l}\text { TV鑑 } \\
\text { 賞 }\end{array}$ & 居室 & おやつ & 居室に移動、部屋にて、話し込屯、拈菓子着替え持参 & & & & & & & & & O & & & & \\
\hline 29 & & \begin{tabular}{|l} 
居室 \\
\end{tabular} & 女 & 㞸 & $B 2$ & 代 & 娘 & 居室 & \begin{tabular}{l|l|l} 
睡眠 \\
\end{tabular} & $\begin{array}{l}\text { 居室 } \\
\text { 部 }\end{array}$ & 会話· & 部屋で静が炕会話、その後、建物周りの散策道を車椅子を押して散歩 & & & & & & & 0 & & & & & & \\
\hline 30 & 設居 & \begin{tabular}{|l}
4 居室 \\
\end{tabular} & 女 & 否 & B2 & 代 & 息子 & 居室 & 睡眠 & 居室 & 会話 & 部屋の空側のイスに座って会話 & & O & & & & & & & & & & O & \\
\hline 31 & 室 & 居室 & 女 & 甭 & $\mathrm{c2}$ & 代 & 息子 & 居室 & 睡眠 & 居室 & 会話 & 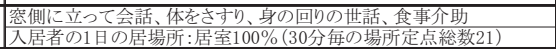 & & 0 & & & & & & & & & & 0 & \\
\hline 32 & 個 & 個室 & 男 & 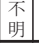 & B1 & 代 & 妻 & 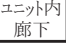 & 徘徊 & 居室 & 会話 & 奥さんが来て稻やがなりり居室にてドアを閉めて会話していた & & & & & & & & & & & 0 & & \\
\hline 33 & & 個室 & 男 & 㞸 & $B 1$ & 代 & 妻 & 居室 & 会話 & 食堂 & 食事 & 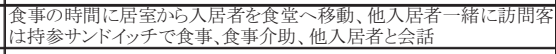 & & & & & & c & & & & & & & \\
\hline 34 & $\begin{array}{l}\mathrm{K} \\
\mathrm{T}\end{array}$ & 年室 & 女 & \begin{tabular}{l|l} 
否 \\
\end{tabular} & 不 & 代 & 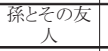 & 居室 & 無為 & 居室 & 会話 & 孫が友達と 3 人で訪れるとどッ゙サイドでー生懸命話をしていた。 & & & 0 & & & & & & & & & & \\
\hline 35 & & 個室 & \begin{tabular}{|l|l} 
苼 \\
\end{tabular} & 78 & B1 & $\begin{array}{l}\text { 不 } \\
\end{array}$ & 友人 & 居室 & \begin{tabular}{|l|l|} 
聴く \\
\end{tabular} & 居室 & 会話 & 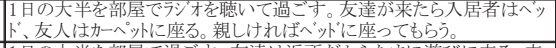 & ○閉 & & & & & & & & & & & & \\
\hline 36 & 個 & 個室 & 性 & 87 & $\mathrm{~A} 2$ & $\begin{array}{ll}\text { 不 } \\
\text { 明 }\end{array}$ & 友人 & 居室 & \begin{tabular}{|c|c|} 
T笽 \\
\end{tabular} & 居室 & 会話 & 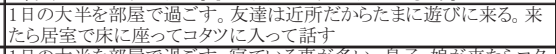 & ○閉 & & & & & & & & & & & & \\
\hline 37 & & 個室 & $\begin{array}{l}\text { 卒 } \\
\text { 性 }\end{array}$ & \begin{tabular}{|l|} 
不 \\
\end{tabular} & A1 & 明 & 息子·娘 & 居室 & \begin{tabular}{l|l|l} 
睡眠 \\
\end{tabular} & 居室 & ふやっ & 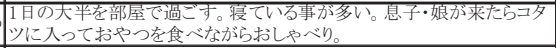 & ○閉 & & & & & & & & & & & & \\
\hline & & & & & & & & & & & & 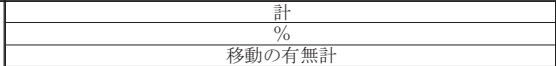 & \begin{tabular}{|l|l}
7 \\
44 \\
\end{tabular} & & \begin{tabular}{|l|l|}
$\frac{1}{6}$ \\
16
\end{tabular} & & & & & & & & & \begin{tabular}{|l|l|}
12 \\
$75 \%$ \\
移動机地
\end{tabular} & \\
\hline & & & & & & & & & & & & & & & $43 \%$ & & & & & 779 & & & & 16事例 & \\
\hline
\end{tabular}


が、その内 4 事例（表 4 の番号 $9 \cdot 19 \cdot 23 \cdot 29$ ）がユニット外の廊 下・玄関ホール・建物周り散策道へ移動している。ユニット内の食 堂から居室へ移動した事例は 21 事例中 6 事例（約 3 割）あるが、そ の内個室は 5 事例、個室的多床居室注11) は 1 事例、多床居室は無い。 具体的な事例をみると表 4 の番号 $2 \cdot 7 \cdot 10$ の個室へ移動した 3 事例 では水入らずでおやつ・お茶・会話を楽しんでいる状況が窥える。 食堂からユニット外へ移動した事例は 21 事例中 6 事例（約 3 割）あ る。表 4 の番号 8 では景色を見に移動し、表 4 の番号 $15 \cdot 20 \cdot 21$ ・ 22 の 4 事例ではユニット外の玄関ホールで訪問受入居者と訪問客だ けでおやつ・お茶・散歩を楽しんでいる様子が窥える。つまり、接 客により訪問受入居者が居た場所から移動する事例では、訪問受入 居者と訪問客だけで過ごすため、ユニット内の個室とともに、ユ ニット外のおやつ・お茶・散歩などができる場所が接客場所の選択 要因となっている。

\section{3. 接客時の他入居者への関わり}

入居者一人ひとりは訪問客が多くは訪れていない注10) 中、多くの 入居者が社会との関わり注12) を持つために接客に他入居者が参加で きる環境も大切であると考える。そこで、接客時に他入居者がいか に関わりを持っているかその特徵と関わりや寸い空間の「しつら え」について考察する。

\section{$3-1$. 他入居者の関わり内容}

接客時に他入居者が同じテーブルに居合わせた事例は、調查で得 られた「しつらえ」がわかる全事例 144 事例中 7 事例 (5\%) と少 ない $\left(\right.$ 表 $\left.5^{\text {注 } 13)}\right)$ 。接客場所をみると 7 事例全て食堂である。接客行 為は食事が 4 事例、お茶・おやつ注 14) が 1 事例で飲食が 8 割弱を占 め、他入居者同席の多くが飲食時である。

\section{3-2. 他入居者が関わりやすい「しつらえ」}

7 事例中で接客時の状況がわかる 5 事例をみると、図 1 の番号 1 （表 4 の番号 3 ）「訪問受入居者・訪問客はスタッフが用意したテー ブル席にすわり参加者の会話に笑顔で答える」、図 1 の番号 2 (図 4 の番号 1 ) ・番号 4 （表 4 の番号 33 ）「訪問客は食堂テーブル席の訪 問受入居者の隣に座り、食事を一緒に食し、他入居者に話しかけ る」、図 1 の番号 3 (表 4 の番号 12 ) ・番号 5 (表 4 の番号 26)「スタッ フの話し掛けよってテーブル席に訪問客は座り、他入居者と共に会 話寸る」であった。 5 事例中、図 1 の番号 2 を除く 4 事例では食堂 テーブルで訪問受入居者の隣に訪問客の席を確保するスペースが あった。また、3 事例ではスタッフの話しかけ・席の用意などスタッ フの働きかけから訪問客が食堂テーブル席に着座していた。

つまり、接客が少ない入居者にとって訪問客と接する機会とし て、複数の入居者が同席する食堂テーブルは大切な「しつらえ」で あり、食事時に入居者が座る席数に対し若干のゆとりをもたせた席 数のテーブル設置とスタッフの働きかけよって他入居者が接客に参 加する環境が生まれることがわかる。

\section{4. 接客時のスタッフの関わり}

調查対象入居者の寝たきり度注15) がわかる 5 施設の中で 3 施設が 平均寝たきり度 B ランク以上（表 3 ） と自立歩行する入居者は少な く、訪問客に対し、入居者に代わってもてな寸手助けをする存在と してスタッフの関わりが大切と考える。そこで、接客時にスタッフ
表 5 他入居者参加状況

\begin{tabular}{|c|c|c|c|c|c|c|c|c|c|c|}
\hline \multirow[b]{2}{*}{ 接客場所 } & \multirow{2}{*}{$\begin{array}{l}\text { 廊下. } \\
\text { 共用. } \\
\text { 外部 }\end{array}$} & \multirow[b]{2}{*}{$\begin{array}{l}\text { 居 } \\
\text { 間 }\end{array}$} & \multirow[b]{2}{*}{$\begin{array}{l}\text { 食 } \\
\text { 堂 }\end{array}$} & \multirow[b]{2}{*}{ 居室 } & \multirow[b]{2}{*}{ 計 } & \multicolumn{5}{|c|}{ 食堂における接客行為 } \\
\hline & & & & & & 会話 & 食事 & $\begin{array}{c}\text { おやつ・ } \\
\text { お茶 }\end{array}$ & $\begin{array}{l}\text { レ列エー } \\
\text { ション }\end{array}$ & 計 \\
\hline $\begin{array}{c}\text { 同席他入居 } \\
\text { 者参加 }\end{array}$ & & & 7 & & 7 & 2 & 4 & 1 & & 7 \\
\hline$\%$ & & & $30 \%$ & & $5 \%$ & $25 \%$ & $40 \%$ & $33 \%$ & & $30 \%$ \\
\hline 接客事例 & 43 & 15 & 23 & 63 & 144 & 8 & 10 & 3 & 2 & 23 \\
\hline
\end{tabular}

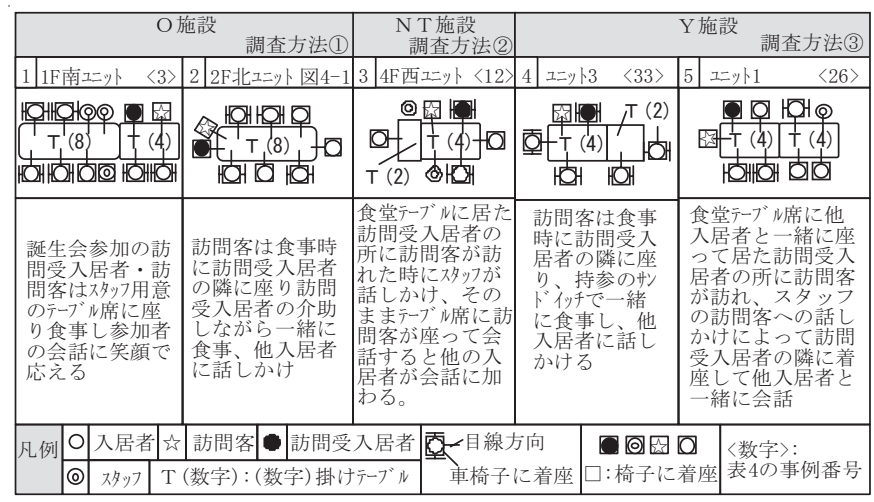

図 1 ユニット内食堂机配置と他入居者参加接客事例

表 6 スタッフの接客支援場所と「しつらえ」

\begin{tabular}{|c|c|c|c|c|c|c|c|}
\hline \multirow{3}{*}{$\begin{array}{l}\text { 接客場所 } \\
\text { ユニット個室 }\end{array}$} & \multicolumn{3}{|c|}{$\begin{array}{c}\text { スタッフが支援した「し } \\
\text { つらえ」 }\end{array}$} & \multirow{2}{*}{\multicolumn{2}{|c|}{$\begin{array}{c}\text { スタッフ支援が } \\
\text { あった事例 }\end{array}$}} & \multirow{3}{*}{$\begin{array}{c}\text { 支援/各場 } \\
\text { 所事例 } \\
18 \%\end{array}$} & \multirow{3}{*}{$\begin{array}{c}\begin{array}{c}\text { 各場所 } \\
\text { 事例 }\end{array} \\
28\end{array}$} \\
\hline & \multirow{2}{*}{$\frac{\text { 椅子 }}{4}$} & \multirow{2}{*}{$\begin{array}{c}\begin{array}{c}\text { テー } \\
\text { ブル }\end{array} \\
3\end{array}$} & \multirow{2}{*}{$\begin{array}{c}\begin{array}{c}\text { お茶 } \\
\text { 出し }\end{array} \\
2\end{array}$} & & & & \\
\hline & & & & 5 & $28 \%$ & & \\
\hline ユニット食堂 & & & 5 & 5 & $28 \%$ & $22 \%$ & 23 \\
\hline ユニット居間 & & & 6 & 6 & $33 \%$ & $40 \%$ & 15 \\
\hline ユニット廊下 & 1 & & 2 & 2 & $11 \%$ & $100 \%$ & 2 \\
\hline その他の場所 & & & & & & & 76 \\
\hline 計 & 5 & 3 & 15 & 18 & $100 \%$ & 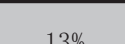 & 144 \\
\hline 言 & $28 \%$ & $17 \%$ & $83 \%$ & & & $13 \%$ & 144 \\
\hline
\end{tabular}

表 7 個室に整備されている着座して利用する「しつらえ」

\begin{tabular}{|c|c|c|c|c|c|c|c|c|}
\hline しつらえ & $\begin{array}{l}\text { デー } \\
\text { ブル }\end{array}$ & $\begin{array}{l}\text { 椅 } \\
\text { 子 }\end{array}$ & 畳 & $\begin{array}{c}\text { こた } \\
\supset\end{array}$ & 絨建炎 & リファー & $\begin{array}{l}\text { 空力ウ } \\
\text { 夘- } \\
\end{array}$ & $\begin{array}{c}\text { しつらえ把 } \\
\text { 握室数 }\end{array}$ \\
\hline O施設 (ユニット個室) & 5 & 7 & 4 & & 1 & 4 & & 20 \\
\hline $\mathrm{NT}$ ・N・E（ユニット個室） & & 5 & & 4 & 5 & 1 & 14 & 23 \\
\hline E施設 (夫婦室) & 1 & 1 & & & & & & 1 \\
\hline 計 & 6 & 13 & 4 & 4 & 6 & 5 & 14 & 44 \\
\hline$\%$ & $14 \%$ & $30 \%$ & $9 \%$ & $9 \%$ & $14 \%$ & $11 \%$ & $32 \%$ & $100 \%$ \\
\hline
\end{tabular}

が訪問客にどのような手助けをしているか事例で示し考察する。

\section{4-1．スタッフの対応内容と「しつらえ」}

「しつらえ」のわかる 144 事例の中で接客時にスタッフの支援が あった事例は 18 事例（1 割強）と、支援が少ない。また、その全て がユニット型施設であった（表 6 ）。支援が行われた室をみると、ユ ニット内の居間、個室、食堂が共に 3 割前後を占める。支援内容は、 「椅子」・「テーブル」を運ぶ、「お茶を出す」の 3 つの行為が行われ た。中でも「お茶を出す」は支援事例の 8 割強の例で行われている。 つまり、ユニット内では、スタッフが入居者に代わって「お茶を 出す」支援がしやすい環境であると推察できる。

次に個室をみると「椅子」・「テーブル」支援は個室と廊下のみで あること及び、ユニット型施設個室（着座に利用する「しつらえ」 のわかる 44 室) で椅子 3 割、テーブル 1 割強と整備十分でない（表 7）ことから、個室では「しつらえ」の整備不足からスタッフが「テー 
ブル」「椅子」を運び入れる支援を行っていると推察できる。

\section{4-2. スタッフの滞在場所と接客場所}

スタッフの 1 日の滞在場所をみると、 $\mathrm{O} ・ \mathrm{~N} T$ 施設共に、一番 多い滞在場所は食堂で、次に居室、台所の順である（図 2 )。また、 居室と食堂を合わせた接客事例（表 8 ）は 6 割あり、スタッフの滞 在が多い場所で接客がおこなわれている。

図 3 に具体的事例を示す。スタッフの手助けの流れは「スタッ フは訪問客が訪れたことに気づき居室に行き訪問受入居者を起こ す。次にリネン室に椅子、テーブルを取りに行き居室へ運ぶ。そ の後、台所でお茶を準備し居室へ運び食堂に戻る。訪問受入居者 と訪問客は居室で「水入らず」でお茶を飲みながら会話。」である。 つまり、これは、スタッフの手助けによって水入らずの接客が実 現することを示している。また、スタッフの手助けがしや寸い接 客場所は、スタッフの中心的な活動場所に近く、スタッフが訪問 客の訪れる状況を把握しやすい場所となっている。

\section{5 . 長時間滞在型接客の特徵と「しつらえ」}

訪問客が 3 時間以上滞在した長時間滞在事例は 10 事例である (表 9)。これは、滞在時間がわかる 201 事例の $5 \%$ と施設では長時 間滞在は少ないことがわかる。しかし、少ない事例ではあるが共 通する傾向を持ち、さらに、宿泊への可能性を持つ事例も含まれ ていることから、施設における長時間滞在事例についてその特性 と対応寸る「しつらえ」の要件について考察する。

\section{$5-1$. 長時間滞在時の訪問客の滞在場所}

長時間滞在 10 事例の中で滞在中の状況のわかる 8 事例（表 10 ) についてみると、宿泊滞在事例を除く 7 事例を合せた延滞在時間 は2058 分あるが、その中で滞在中に訪問客が一時的に訪問受入居 者から離れた時間は、630 分と延滞在時間の約 3 割で、その内訳は 食事・処置等施設プログラムによる止むを得ない事例 150 分 (2 割 強）、訪問客の休㽞によるもの 480 分（8 割弱）であった。

次に、離れている時間の訪問受入居者と訪問客の滞在場所をみ ると、宿泊例も含む訪問受入居者が独りで居る時間 2310 分の内、 1980 分 (8 割強) が訪問受入居者と訪問客が共に同じユニッ ト・クラスタ注17) 内に居る。その訪問客の滞在場所は、ク ラスタ内ではデイルーム、ヌック（廊下に設けられた談話 スペース)、ユニット内では和室（就寝）、居間であった。 ユニット内の和室の事例は、宿泊滞在事例（表 10 の番号 図 4-1) である。

\section{$5-2$. 訪問客の宿泊場所}

宿泊事例は対象 222 事例の中で 1 例のみであるが、訪問 客のユニット内への宿泊ができている点で重要な事例であ る。その宿泊状沉を見ると、延滞在時間数 3240 分の内、就 寝が 1200 分ある（表 10 の番号図 4-1)。3 名の訪問客が、個 室で全員就寝が難しい為、同じユニット内の和室（9 疊）で 障子を閉めて就寝する。和室は居間と領域を明快に分ける 小上がり・畳・障子の「しつらえ」、複数人に対応できる 広さにより家族が同じユニット内に宿泊できる場所となっ ている。

\section{$5-3$. 長時間滞在時の訪問客の滞在場所選択要因}

長時間滞在時中、止むを得ない場合を除いて訪問受入居

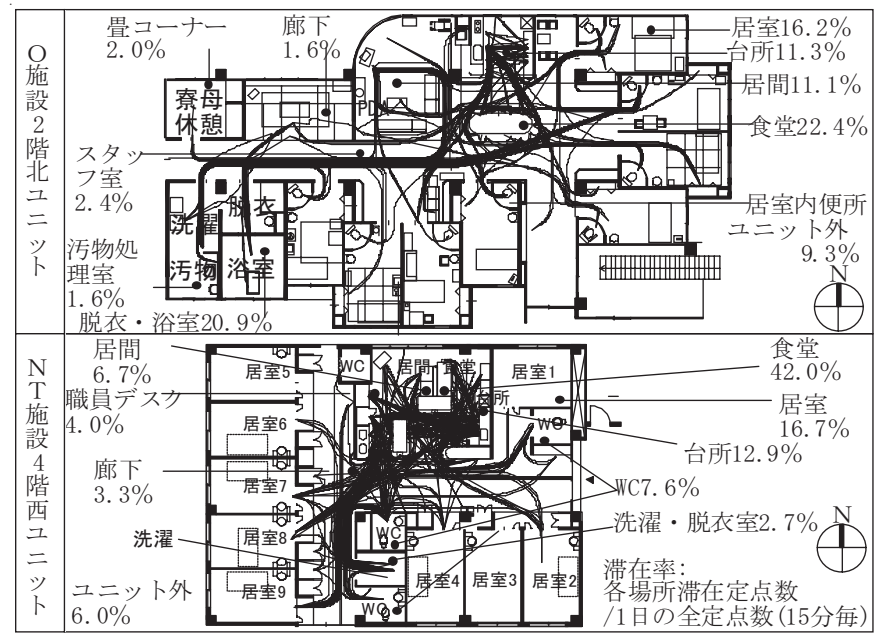

図 2 スタッフの介護動線と滞在率(日勤 $8: 30 \sim 16: 00$ ) 注 16

表 8 接客場所

\begin{tabular}{|c|c|c|c|c|c|c|c|c|c|c|}
\hline 接客場所 & 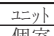 & $\begin{array}{l}\text { 多店 } \\
\end{array}$ & 党 & 間 & & 店下下 & & 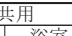 & 外部 & 計 \\
\hline & $\frac{1}{28}$ & 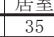 & $\frac{1023}{23}$ & $\frac{|r| r|r|}{15}$ & 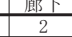 & $\frac{1}{2}$ & 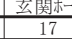 & 浴㗌 & $\frac{\text { 外部 }_{19}}{19}$ & 144 \\
\hline 接客 & $19 \%$ & $25 \%$ & $16 \%$ & $10 \%$ & $1 \%$ & $1 \%$ & $12 \%$ & $2 \%$ & $13 \%$ & 100 \\
\hline
\end{tabular}

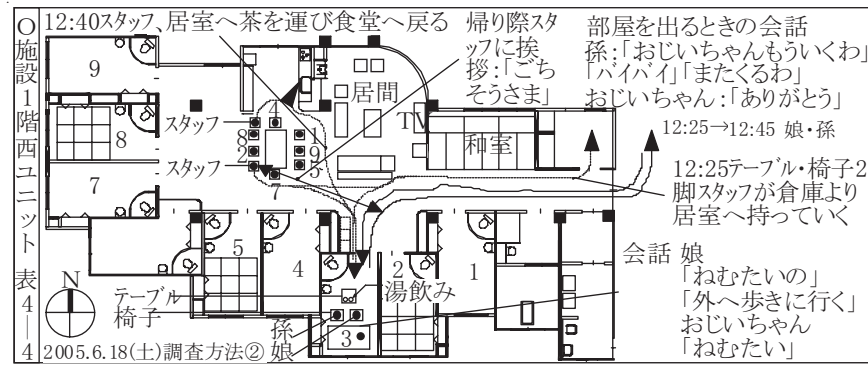

図 3 スタッフの対応事例（ $\mathrm{O}$ 施設）

表 9 訪問客の滞在時間

\begin{tabular}{|c|c|c|c|c|c|c|c|c|c|c|c|}
\hline 施設名 & 0施竐 & NT施諨 & 役 TG施棓 & 没 $N$ N施設 & E施䛠 & 没 Y施 & 昰設 & KT施設 & 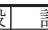 & t十 & $\%$ \\
\hline$\sim 3$ 時間末満 & 20 & 55 & 44 & 12 & 1 & 10 & 10 & 49 & & & $95 \%$ \\
\hline 3 時間以上 & 1 & 1 & 2 & & & & 2 & 3 & & & \\
\hline 宿泊 & 1 & & & & & & & & & & $5 \%$ \\
\hline 計 & 2 & 1 & 2 & & & 2 & $\frac{2}{2}$ & 3 & & 10 & \\
\hline $\begin{array}{l}\text { 合計 } \\
\text { 数：接客時間 }\end{array}$ & $\frac{22}{5 \infty 2}$ & $\begin{array}{l}56 \\
\text { 例数 }\end{array}$ & 46 & 12 & 1 & 12 & & 52 & 2 & & $100 \%$ \\
\hline
\end{tabular}

表 10 長時間滞在型の接客事例

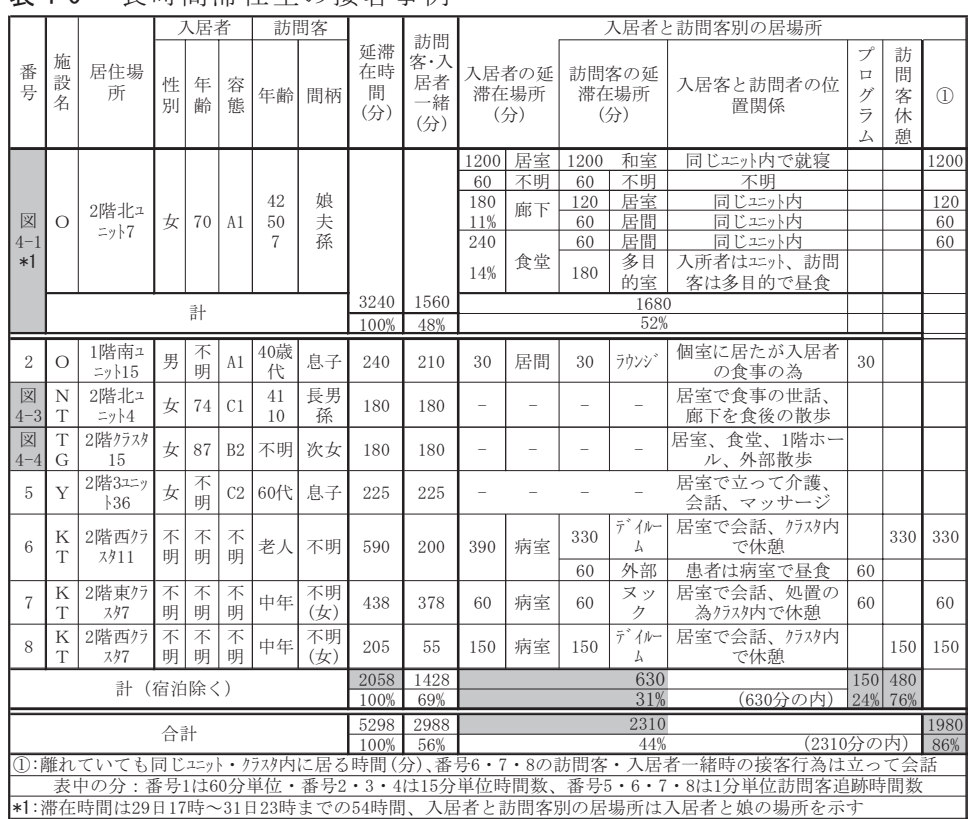


者と訪問客は一緒に居ることが多いが、訪問客は訪問受入居 者から離れる場合においても出来る限り近くに居る。その場 合の訪問客の滞在場所は、クラスタ・ユニット内で入居者の 多くが日中過ごす居室・食堂（表１１）を避けた、他入居者の 利用が少ないスペースが挙げられる。

\section{$5-4$. 長時間帯在時に接客場所を移動する要因}

8 事例の接客行為をみると、接客場所を移動して行為を変え ている事例は 3 事例 $(3 / 8)$ ある。表 10 の番号図 4-3 は、食後 の散歩で回廊にある空から外の景色を見て、その後居室に戻 りベットと椅子に座り会話をして過ごしている（表 4-8、図43)。表 10 の番号図 4-4 はクラスタ外の喫茶コーナーでテーブル に着いて飲食している（表4 の番号 19、図4 の番号4）。宿泊滞 在事例（表 10 の番号図 4-1）では、ユニット外の大浴場で一緒 に入浴、他ユニット食事会に招かれ食堂テーブルに着いて食 事、ラウンジのテーブルに着いて会話、屋外のボランティア 八ウス注18) 和室のコタツテーブルを囲み食事と、施設に設けら れた多様な空間を一緒に利用している（表 4 の番号 3 、図 4 の 番号 1$)$ 。つまり、これら長時間居る間に一緒に移動する事例 では、複数の接客行為を場所を移動して行い、その場所は訪 問客と一緒に利用できる「しつらえ」を有していることが接 客場所選択の要因となっている。

\section{6. 接客場所における接客行為と「しつらえ」}

高齢者居住施設における主な接客場所は居室、食堂、居間、 廊下、玄関ホールであった（表 8 )。これら各室において、接 客行為と関係した「しつらえ」の全体的な傾向を把握する。

次に、具体的に「しつらえ」の配置と接客の状況をみるこ とによって、各空間の特徵と要件について考察する。

尚、接客はプライベート性が高く、具体的な状沉を把握す ることは難しく、少ない事例数となったが、出来る限り整理、 分類を試みた。

\section{$6-1$. 居室における接客行為と「しつらえ」}

居室で行われた行為 63 事例のうち、会話が 8 割弱、おやつ・お 茶が 2 割弱でこの 2 つの行為で大半を占める (表 12 )。室種別にみ ると、おやつ・お茶の行為 10 事例の 9 割が個室注19) で行われた事例 であった。会話 49 事例の約 7 割が 4 床室注19) であった。

おやつの行為 10 事例をみると（表 12 ）、訪問客は全て椅子また はベッドに着座し、7 割がテーブルを利用している。テーブル利用 のない 3 事例においても、ベッドにおやつを広げてベッドをテー ブル代わりに利用し、入居者は椅子あるいは車椅子に腰掛けてい た。次に、テーブルの種類をみると、小テーブル（2 人掛け）の利 用が 9 割弱、4 人掛け以上のテーブルの利用は 1 事例しかなかった。

一方、会話の行為 49 事例をみると、訪問客は 4 床室 35 事例中 8 割弱、個室 14 事例中 4 割弱が立位でテーブルの利用はみられない。

つまり、会話では接客時に「しつらえ」の利用が少なく訪問客 は立位が多いが、おやつ・お茶の接客行為は訪問客の着座と湯飲 み・おかしを置く椅子と小テーブルの利用が多い。

次に具体的事例（図 5 ）では、実床面積注20) でみると、8.5 m² 上の個室（図 5 の番号IV) でおやつ・お茶を可能にする「しつら え」配置がみられる一方、同じ $8.5 \mathrm{~m}^{2}$ 以上ある個室 $\mathrm{O}$ 施設事例（図
表 $11 \mathrm{NT}$ - O 施設ユニット入居者の 1 日の居場所

\begin{tabular}{|c|c|c|c|c|c|c|c|c|c|c|c|}
\hline 居場所 & 外部 & ユニット外 & 居間 & 居室 & 食堂 & 浴室 & 洗面 & 便所 & 廊下 & 和室 & 計 \\
\hline \multirow{2}{*}{ NT施設 } & & 12 & 54 & 101 & 174 & & 4 & 34 & 6 & & 385 \\
\hline & & $3 \%$ & $14 \%$ & $26 \%$ & $45 \%$ & & $1 \%$ & $9 \%$ & $2 \%$ & & $100 \%$ \\
\hline \multirow{2}{*}{ O施設 } & 17 & & 55 & 94 & 155 & 7 & & & 29 & 13 & 370 \\
\hline & $5 \%$ & & $15 \%$ & $25 \%$ & $42 \%$ & $2 \%$ & & & $8 \%$ & $4 \%$ & $100 \%$ \\
\hline
\end{tabular}

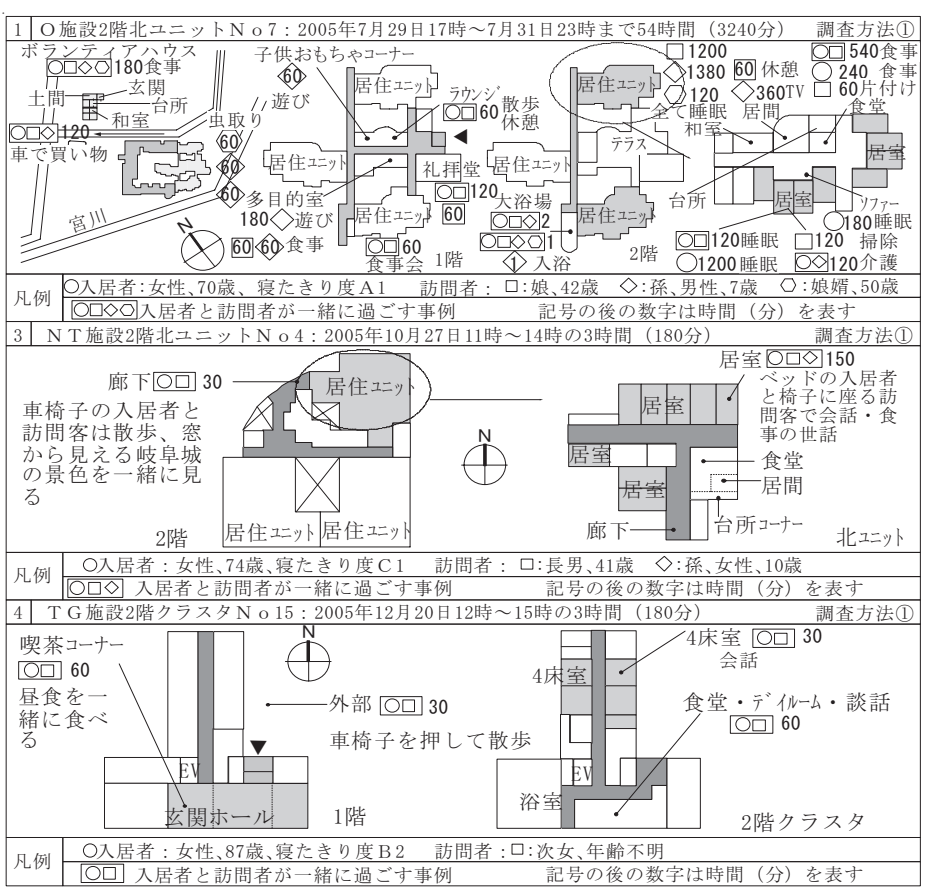

図 4 長時間滞在型の訪問客滞在場所事例

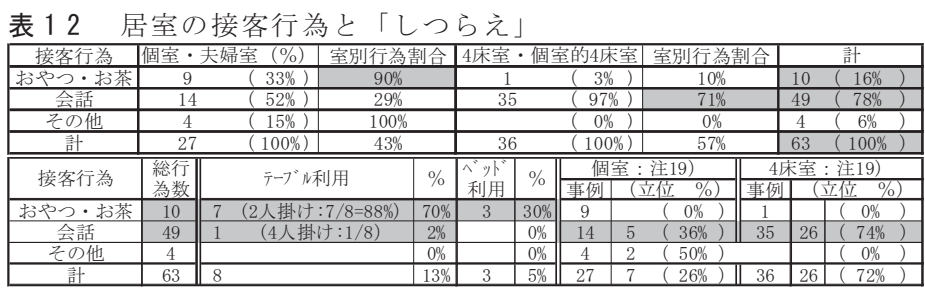

5 の番号 I -2) 及び個室的多床室 Y 施設事例（図 5 の番号 II -2、III6 ）で「しつらえ」が設けられていない事例があることから居室タ イプ・実床面積規模だけが要因でないと考える。

そこで、入居者のベッドへの動線と「しつらえ」整備状況をみ ると、居室の出入り口側で接客が行われる事例（図 5 の番号 I ）は、 ベッドに腰掛ける（I - 1)、立って会話する（I - 2) と小テーブル・ 椅子の利用がみられない。これは、入居者のベッドへの動線が接 客場所を横断する為、接客に利用する「しつらえ」設置が難しい 為であると考える。ベッドサイド間口注 21）の片側が広い事例（図 5 の番号 II ）及びほぼ同じ間隔である事例（図 5 の番号 III）は、入 居者のベッドへの動線と接客場所が重なり、接客に利用するテー ブル設置がみられないが、図 5 の番号 II ではベッドサイド間口が $1.5 \mathrm{~m} \cdot 1.2 \mathrm{~m}$ で椅子の利用（II - 1・II - 3 ）が見られる。 II -3 をみ ると訪問受入居者が車椅子に、訪問客が折りたたみ椅子に座り会 話しているが、車椅子の幅注22) を考えるとベッドサイドに $57 \mathrm{~cm}$ の 間口が残り椅子を置くことを可能にしていると推察する。

一方、図 5 の番号IIIではいずれもベッドサイド間口が $95 \mathrm{c} \mathrm{m}$ 以下 で椅子の設置もみられない。III - 2 ではベッドサイドに置かれた訪 問受入居者の車椅子に訪問客が座って会話しているが、車椅子の 
幅を除くとベッドサイドの空き間口は $22 \mathrm{~cm}$ で椅子を置くこと ができていない。

ベッドを壁際に寄せた事例（図５の番号IV）は、ベッドと「し つらえ」間に車椅子幅程度の空きがあり、「しつらえ」に影響 なく入居者はベッドへアプローチできる。また、ベッドサイド 間口がいずれも $1.8 \mathrm{~m}$ 以上あり、車椅子幅を除いても $1 \mathrm{~m}$ 以上 の間口が残る。その場所では、こたつでおやつを食べる（IV 1)、ソファー・椅子に座ってテーブルの茶を飲む (IV - 2)、テー ブルを囲んで椅子・車椅子に座って会話（IV-3）が行われてい た。

つまり、入居者のベッドへの動線とベッドサイド間口が、接 客に利用する小テーブルと椅子の設置に影響し、ベッドへの動 線を除くベッドサイド間口が $1 \mathrm{~m}$ 以上ある事例では飲食物が置 ける小テーブルと椅子・こたつあるいはソファーの「しつら え」が設置され、接客に利用されている。

\section{6-2. 食堂における接客行為と「しつらえ」}

食堂で行われた「しつらえ」のわかる接客行為は2 3 例あっ

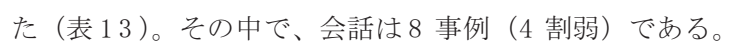

食事は 10 事例（4 割強）で全て食事の施設プログラム中に訪 問客が同席しておこなわれている。おやつ・お茶は 3 事例（約 1 割)、レクリエーションは 2 事例（1 割弱）と少ない。関係し た「しつらえ」をみると、会話・食事では、全ての事例で 6 人 掛け以上の大きなテーブルを利用している。一方、おやつ・お 茶・レクリエーションの行為では、 4 人掛け以下のテーブルの 利用があった。

食堂の具体的な接客状況をみる（図 6 )。 $\mathrm{Y}$ 施設図 6 の番号 $\mathrm{d}$ 型では、訪問受入居者と訪問客は居室でドアを閉めて水入らず で過ごしていた（表 4 の番号 32 ）が食事のため居室から出て食 堂の 4 人掛けと 2 人掛けを繋いだテーブルで他の入居者と囲み 共に食事をしている。

一方、N施設東ユニットでは、普段から、食事時には、スタッ フによってテーブルをつなげられ入居者が一緒に大きなテーブ ルで食事をし、食事以外の時間はテーブルを分割して、入居者 が個々に別れて、テーブルを利用している。食堂においてテー ブルレイアウトを1 日の中で変える施設はN施設のみである。 図 6 の番号 $\mathrm{b}$ 型 1 ( $\mathrm{N}$ 施設) では一つのテーブルで二人きりで 趣味の将棋を楽しんでいる入居者夫婦の所へ訪問客が来て横で 観戦して一時を過ごしている。

つまり、食堂は他入居者が同席の中で接客が行われる特徴 (図 1 、図 6 の番号 $\mathrm{d}$ 型) をもつ場所であるが、N 施設の「4人 掛けテーブルを連結あるいは離すといった可変配置」では他の テーブルと離して配置された 4 人掛テーブルで水入らずの接客 が生まれていた。

このことは、食堂ではテーブルの大きさ・配置方法によって 接客の容態が変わることを示している。

\section{$6-3$. 居間における接客行為と「しつらえ」}

居間での接客は、接客事例の 1 割と少ない（表 8 ）が、具体事例 をみると（図 6)、暖炉を囲んだ事例（図６のb 2)、一緒にソファー に並んで座って、前のテーブルにみかんとお茶を置いて大型テレビ で観戦し会話した事例（図６の a 型1）がある。これら事例は、い

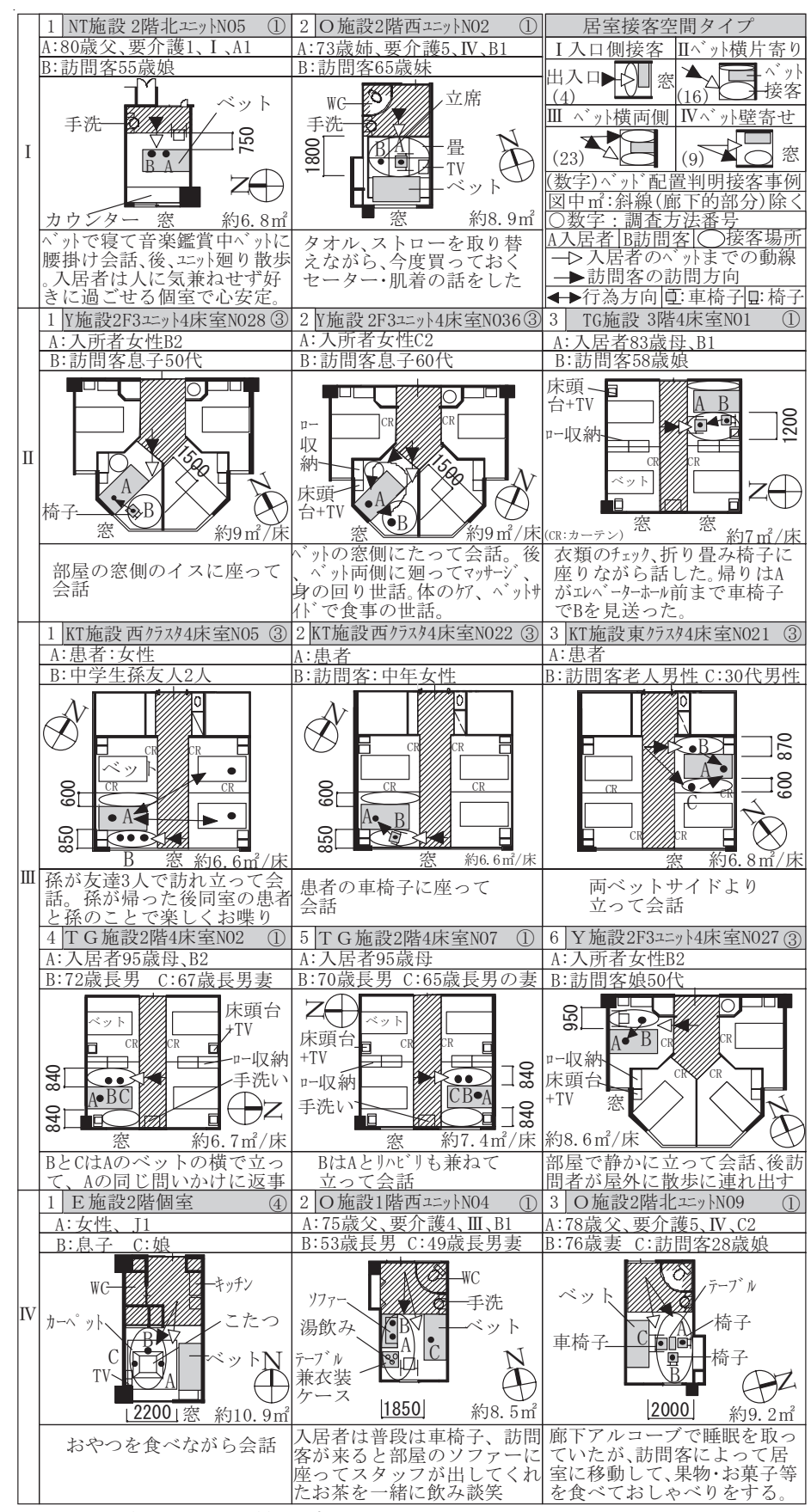

図 5 居室における接客事例

表 13 食堂の接客行為と「しつらえ」

\begin{tabular}{|c|c|c|c|c|}
\hline 行為 & 関係 L & - $5 \dot{2}$ & \multirow{2}{*}{\multicolumn{2}{|c|}{$\begin{array}{c}\text { 食堂における接各事 } \\
\text { 例数 }\end{array}$}} \\
\hline 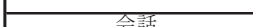 & 4人掛け以下テーフ ル & 6人掛け以上テー7 N & & \\
\hline |食事 (食事プログラム時) & & $\frac{8}{10}$ & $\frac{8}{10}$ & $35 \%$ \\
\hline おやつ・お茶 & 1 & 2 & $\frac{10}{3}$ & $13 \%$ \\
\hline 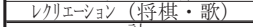 & 2 & & 2 & $9 \%$ \\
\hline 訪 & 3 & 20 & 23 & $100 \%$ \\
\hline
\end{tabular}

表 14 居間の接客行為と「しつらえ」

\begin{tabular}{|c|c|c|c|c|c|c|c|c|c|c|c|}
\hline \multirow{3}{*}{$\begin{array}{l}\text { 利用した } \\
\text { 「しつらえ」 }\end{array}$} & \multicolumn{4}{|c|}{ 入居者·訪問客 } & \multicolumn{3}{|c|}{ 入居者 } & \multicolumn{2}{|c|}{ 訪問客 } & \multirow{2}{*}{\multicolumn{2}{|c|}{$\begin{array}{l}\text { 居間における } \\
\text { 接客事例数 }\end{array}$}} \\
\hline & $\overline{\bar{T}}$ & テーブル(L) & TV & 暖炉 & 車椅子 & 椅子 & ソファー & 椅子 & ソファー & & \\
\hline & & $\frac{7}{47 \%}$ & $\frac{6}{40^{\circ}}$ & $\frac{7}{47 \%}$ & $\frac{4}{2706}$ & & $\frac{11}{73 \%}$ & \begin{tabular}{|c|}
4 \\
270
\end{tabular} & $\begin{array}{r}13 \\
870\end{array}$ & 15 & $100 \%$ \\
\hline $7 \boldsymbol{7} /(4)$ & 大掛量 & $\frac{41 \%}{1-7 \pi}$ & & & TV: & & & $125 \%$ & & & \\
\hline
\end{tabular}

ずれも他入居者は居間には居ず、入居者と訪問客だけの領域とし て利用されている点では個室と同じである。しかし、「しつらえ」 は居室では設置が難しい暖炉・大型テレビ・ソファー（大型）が 整備され（表14)、居室の「しつらえ」の整備不足を補うことが できる接客空間であることを示している。 
次に、居間の配置（図 6) をみてみると、 $\mathrm{a}$ 型 $1 、 \mathrm{~b}$ 型 $1 \cdot 2$ は、 接客スペースとして利用されているが $\mathrm{c}$ 型 1 は接客事例が無 い。c 型 1 居間は食堂テーブルに囲まれ、さらに、着座するソ ファーがテレビと食堂テーブルの間に位置することから、日 中食堂に居る入居者から常に T V への視線を受ける場所と なっている為、訪問客が寄り付き難いと推察できる。又、a 型 $1 、 \mathrm{~b}$ 型 1 の事例があるユニットでスタッフの 1 日の滞在場 所をみると、定時間隔の観察注23) 中 1 回しか居間に滞在してい ない。

つまり、居間は居室には無い「しつらえ」とスタッフの行 き来が少ない配置及び訪問客が廊下から容易に入れる配置に よって接客を可能にしているといえる。

6-4. 廊下・ユニット外における接客行為と「しつらえ」

ユニット内廊下・ユニット外廊下の接客事例はしつらえの わかる事例 144 事例中 4 事例（2\%）と少ない（表 8 )。

具体的な接客事例をみると図 7 の番号 1 では、ユニット近接 の人通りの少ない廊下の密から外の景色を訪問客と一緒に見 ている。図 7 の番号 2 では、入居者が人通りの少ないユニッ 卜内回廊を訪問客と周回し、途中ベンチで休息して外の景色 をみながら会話していた。図 7 の番号 3 では、ユニット内の日 差しの入る廊下端部で外の景色を見ながら一緒にお茶を飲の んでいた。図 7 の番号 4 では、ユニット近接の人通りの少ない 廊下のベンチで椅子に腰掛けおやつを食べていた。

つまり、その全ての事例が人通りの少ない廊下であった。ま た、景色が見える空、椅子、ベンチが置かれ水入らずで滞在 することが出来る場所であった。

次に、玄関ホールの 17 事例をみると、接客行為は飲食が 9 割強と大半を占めている（表 15 )。飲食時の「しつらえ」は全 て 4 人掛けのテーブルを利用している。具体的な事例をみると 図 7 の番号 5 では多床居室を離れ玄関ホールにて訪問受入居者 と訪問客が 4 人掛けのテーブルに着いて施設のボランティアに よる食事・お茶・おやつのサービスを利用している。

つまり、玄関ホールではテーブルの分散配置によって入居 者と訪問客だけの接客を可能にし、飲食のサービスによって 多床室の接客スペースの不足を補っていた。

7. まとめ

本研究により明らかとなった点は、以下のようになる。

\section{（1）接客場所と選択要因}

高齢者居住施設では入居者と訪問客が水入らずで過ごすこ とができる場所へ移動する事例が多く、その場所として、調 查施設では、ユニット内は個室、ユニット・クラスタ外では、 おやつ・お茶・散歩などができる廊下・玄関ホール・建物周り であった。

\section{（2）接客時に他入居者の参加を促す空間}

食堂では食事時に入居者が座る席数に対し若干のゆとりを もたせた席数のテーブル設置とスタッフの働きかけが出来る環境に よって他入居者が接客に参加する環境が生まれていた。これは、普 段から訪問客が少ない施設にとって多くの入居者が外部の人と触れ 合える大切な空間であると考える。

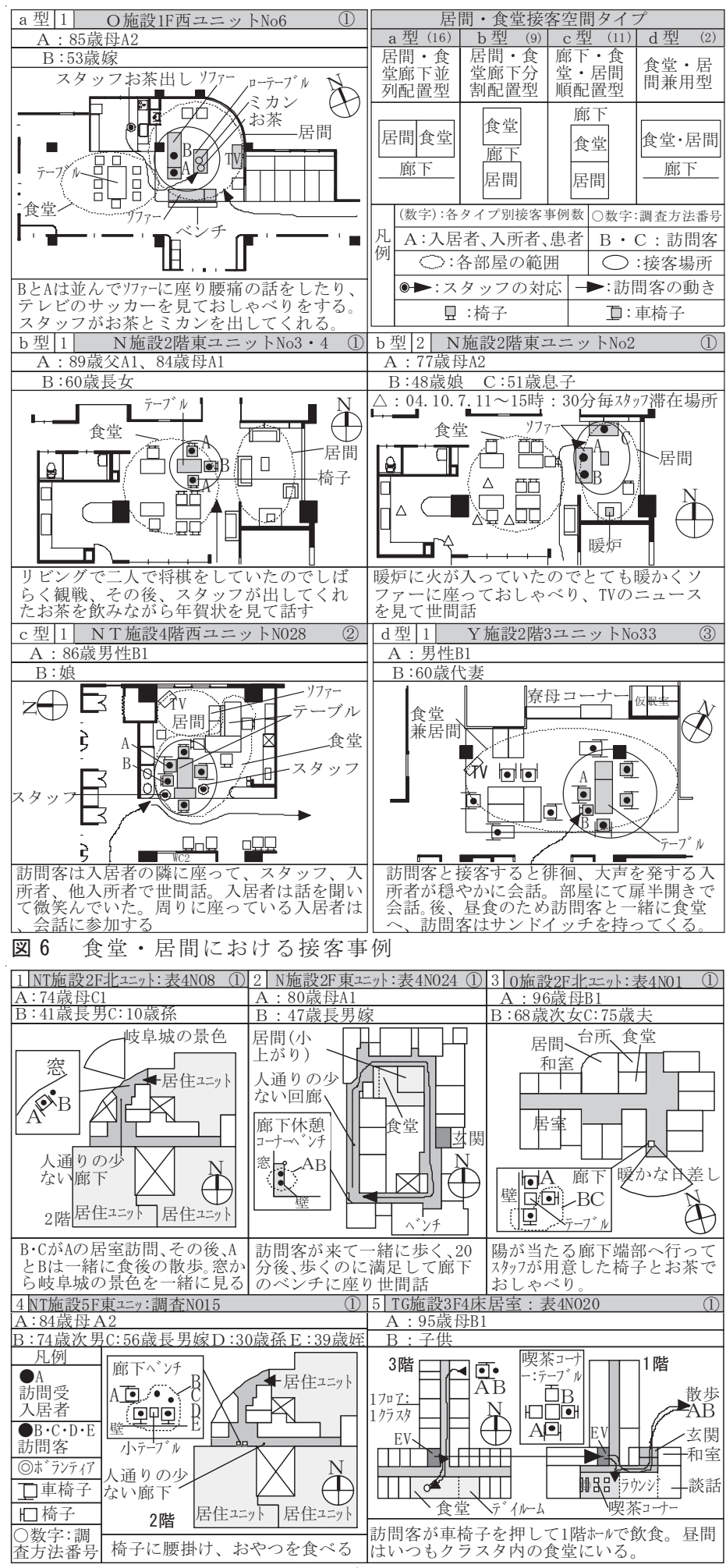

図 7 廊下・ユニット外の接客事例

\begin{tabular}{|c|c|c|c|c|}
\hline 行為 & 関係したしつらえ:4人掛けテーブル & ボランテ仍支援 & 玄関术水 & 客事例数 \\
\hline 会話 & 1 & & 1 & $6 \%$ \\
\hline 食事 & 4 & 4 & 4 & $24 \%$ \\
\hline おやつ・拉茶 & 12 & 7 & 12 & $71 \%$ \\
\hline 計 & 17 (全て他入居者同席なし) & 11 & 17 & $100 \%$ \\
\hline
\end{tabular}

(3) 接客時にスタッフが手助けしやすい空間

スタッフの手助けが訪問受入居者と訪問客の水入らずの接客を実 現することに役立つことが明らかになった。また、スタッフが接客 を手助けしやすい環境はスタッフの中心的な活動場所に近く、ス 
タッフが訪問客が訪れる状況を把握しやすい空間であると考える。

\section{(4) 訪問客が長時間滞在しやすい空間}

長時間滞在事例の内、多くの事例が訪問客は常に入居者の側にい る。訪問客が長時間入居者と共に過ごすためには、入居者と訪問客 が一緒に利用できる「しつらえ」を備えた接客場所を施設の中で複 数有する事が大切であると考えられる。

\section{（5）接客場所に必要な「しつらえ」とその配置の特性}

居室は、ベッドへの動線を除くベッドサイド間口が $1 \mathrm{~m}$ 以上ある 事例では飲食物が置ける小テーブルと椅子・こたつあるいはソ ファーの「しつらえ」が設置され接客に利用されている状況が窅え る。食堂は他入居者が同席の中で接客が行われる特徵をもつ場所で あるが、テーブルの可変配置によって、水入らずの接客を生み、 テーブルの大きさ・配置方法によって接客の容態が変わることを示 している。居間は、居室には無い「しつらえ」設置とスタッフの行 き来が少ない配置及び訪問客が廊下から容易に入れる配置によって 訪問受入居者と訪問客だけで過ごせる場所をつくり出していた。廊 下は、人通りが少なく、外の景色が見れる空や一緒に座れる椅子・ ベンチの設置されている場所で接客が行われていた。つまり、施設 において接客空間は物理的に「しつらえ」が設置されているだけで なく、「しつらえ」の配置と他入居者・人の動線との関係性が接客 に影響していることがわかる。

\section{(6) 今後の課題}

本稿では接客事例を収集し、いままで捉えられていなかった接客 状況を捉えることによって接客空間の整備要件を一つ一つ明確に出 来たと考える。しかしながら、本稿で得られた知見は、十分に全容 を捉えられておらず、さらに多くの事例収集により各要素を構造的 にまとめることが課題である。

謝辞 調査にご協力いただきました入居者及び訪問客、施設関係者 の方々に深く感謝いたします。

\section{注}

注 1) 平成 18 年度介護報酬等の改定について（第 39 回介護給付費分科 会）介護保険制度改革の概要、厚生労働省老健局総務課、2006 年

注 2) 個人的領域：橘は、居住者がその空間に家具や物を持ち込んだ独自 の環境と述べている（参考文献 3 )。

注 3）接客は「客をもてな寸こと」（大辞泉：小学館）の意味を持つが、服 部は、もてなしについて、「ゲストとホストの間に心温まるもてなし が両者に存在し、その背景には互いに認め合い、互いに理解し合い、 互いに助け合い、互いに依存し合い、互いに共存共栄していくの六つ の相互関係を基盤とした共生関係という考えが存在するものである。」 と示し、ホストとゲストが一時を共に過ごし、感動・感激を共有する ことも該当するとしている。つまり、もてなすは「快適に過ごす時間」 を共有することを意味すると考えることができる（参考文献 5 )。

注 4）入居者：本稿では各施設の生活の場として接客空間を捉えているの で入居者・入所者・入院者を示す。又、訪問受入居者は訪問を受けた 入居者を示す。

注 5)「しつらえ」は「ある目的のための設備をある場所に設ける」「部屋 の内装や設備などを飾り付ける」（大辞林第三版松村明編：三省堂）の 意味をもつが、本論では接客時に関わりがあった家具・敷物・浴槽な どの設備、畳・小上がり・襖・空等の内装をいう。

注 6 ）接客場所と接客空間：接客場所は接客が行われるところ、位置。接 客空間は接客の場所や「しつらえ」の相対的な位置関係を表す。

注 7）日本建築学会計画系論文集、N0.616、2007.6、P 42 「表 8 接客時 間と接客行為数」の変化による(参考文献 4 )

注 8 ）介護保険で受けられる施設サービス：社団法人日本医療福祉建築協
会編集：医療・高齢者施設の計画法規ハンドブック、中央法規、2005 年 1 月、P 11 表 1: 4 による。

注 9）小規模単位型（ユニット、ユニット型）：「特別養護老人ホームの設 備及び運営に関する基準」(平成 11 年 3 月 31 日厚生省令第 46 号) では、 「施設の全部において少数の居室及び当該居室に近接して設けられる 共同生活室により一体的に構成される場所（ユニット）ごとに入居者 の日常生活が営まれ、これに対する支援が行われる特別養護老人ホー ム」と規定。従来型：ユニット型に対照するタイプ、一般型：ユニット型竹八ウスに 対照する夕イプ: 三訂版医療・高齢者施設の計画法規ハンドブック（社 団法人日本医療福祉建築協会：編集、中央法規出版、2005.1.20 発行)

注 10）既往論文（参考文献 6：図 3）で、平日入居者 1 人あたりの 1 日訪 問客割合は住居系（ケアハウス等）老人施設 $12 \%$ ・福祉系（特別養護 老人ホーム）老人施設 $13 \%$ と少ないこと、また、全般的には平日に比 べ土日祝日が多い傾向にあることを示している。本稿の調査施設につ いても曜日と接客数の関係は概ね同じ傾向である。

注 11）個室的多床居室：4 人居室であるが、各ベッドに空を設け居室条件 が違うため多床居室と居室タイプを区別した。

注 12) 参考文献 7 では「高齢期にみられる社会関係の減少は他物との情緒 的な親密さとは無関係に高齢者にとって望ましくない」と述べている 注 13 ）表 5 〜表 15 : 表中「空欄」は「0」を示す。

注 14 )「会話」は単独で行われている場合を示す。「お茶」には、会話を 含む、「おやつ」には、会話、お茶を含む。

注 15 )「障害老人の日常生活自立度（寝たきり度）判定基準」（平成 3 年 10 月厚生省）

$\mathrm{J}$ ：何らかの障害を有するが日常生活はほぼ自立しており独力で外出。 1 . 交通機関等を利用して外出する 2 . 隣近所入なら外出する A：屋内での生活は概放自立しているが、介助なしには外出しない

1.介助により外出し日中はほとんどベッドから離れて生活する

2. 外出の頻度が少なく日中も寝たり起きたりの生活をしている

$\mathrm{B}$ : 屋内での生活は何らかの介助を要し日中もベッド上での生活が主 体であるが座位を保つ

1。車椅子に移乗し、食事、排泄はベッドから離れて行う

2.介助により車椅子に移乗する

C：1日中ベッド上で過ごし排泄、食事、着替において介助を要する 1. 自力で寝返りをうつ 2 。自力では寝返りもうたない

注 16） 2005 年 10 月 23 日 N T 4 階西ユニット、2005 年 11 月 29 日O施設 2 階北 ユニットで施設観察調査時に同時に行った介護・看護者追跡調査による。 注 17 ) クラスタ：病室のまとまり（看護単位）と定義する。

注 18 ) ボランテイアハウス: 施設が運営する近くの民家を改造した家、職員とボラ ンテイア2 名で運営する。和室には、コタツとソファーをしつらえている。 注 19 ）個室には、夫婦室を含む。4 床室には、個室的多床室を含む。

注 20）実床面積：居室内の廊下的部分、枋多、便所、手洗いを除いたスペース 注 21)ベッド少仆゙間口:ベッドの縁からベッド脇のカーテン又は壁（廊下的部分・ 手洗い部分を除く) までの長さ

注 22）車椅子幅 630 ：JIS T 9201 手動車い寸(大型) の寸法

注 23 ） 2005 年 6 月 18 日 O 施設 15 分毎、2004 年 10 月 7 日 N施設 30 分毎 のコニッ内定時間隔観察調査では、両施設ともスタッフが居間に居た定時間 隔数（各時間毎にスタッフが居た場所のカウント数）は 1 回であった。

\section{参考文献}

1) 石毛直道: 住居空間の人類学、鹿島出版会、1971

2）林悦子・小滝一正・林玉子：個室空間の住まい方特性、日本建築学会 計画系論文集、No. 517、pp. 131 138、1999.3

3 ）橘弘志・外山義・高橋鷹志・古賀紀江：個室型特別養護老人ホームに おける個室内の個人的領域形成に関する研究、日本建築学会計画系論文 集、No. 500、pp. $133 \sim 138 、 1997.10$

4) 藤枝秀樹・今井正次・木下誠一：施設居住に伴う接客の変容に関する 考察、日本建築学会計画系論文集、No.616、pp. $39 \sim 46 、 2007.6$

5 ) 服部勝人 : ホスピタリティ・マネジメント ポスト・サービス社会の 経営、丸善ライブラリー、1996

6) 藤枝秀樹・今井正次・木下誠一・越智直樹：接客の受け入れ方と接客 場面高齢者療養施設の接客空間計画に関寸る研究、地域施設計画研究 23 (第 23 回地域施設設計研究シンポジウム)、pp. 251〜258、2005.7 7）古谷野亘、安藤孝敏：新社会老年学、ワールドプランニング、2003.4 